\title{
Airborne fungi causing respiratory allergy in patients from Fortaleza, Ceará, Brazil
}

\author{
Fungos anemófilos causando alergia respiratória em pacientes na cidade de Fortaleza, Ceará
}

Everardo Albuquerque Menezes'; Paulo Germano Carvalho²; Emmerson Cristhiano Pereira M. Trindade ${ }^{2}$; Geraldo Madeira Sobrinho3; ;rancisco Afrânio Cunha'; Fábio F. Morato Castro ${ }^{5}$

\section{Asthma \\ Rhinitis \\ Prick test \\ Aspergillus \\ Alternaria \\ Drechslera}

key words

Airborne fungi

\section{abstract}

The dispersal of airborne fungi is made through atmospherical air. Knowledge of anemophilous fungi in a given city is important for the ecological diagnosis and specific treatment of allergic manifestations induced by inhaled allergens. Their use in individuals' allergy is widespread, and probably will remain so in the years to come. The purpose of this research was to make a relationship between the airborne fungi and the patients' respiratory allergy (asthma and rhinitis) from the city of Fortaleza, state of Ceará, Brazil. First a research was made in Fortaleza about the fungal allergens dispersed in atmospherical air. Fungal allergen extracts were made from the ten most predominant moulds in the air, using sodium bicarbonate. The prick tests were made in fifty patients with asthma and rhinitis and in ten healthy persons (with no respiratory allergy). The positive test was made using histamine and the negative test with sodium bicarbonate preparation. The predominant fungi in the air of Fortaleza were: Aspergillus, Penicillium, Curvularia, Cladosporium, Mycelia sterilia, Fusarium, Rhizopus, Drechslera, Absidia and Alternaria. As determined by the prick test: three fungal extracts (Aspergillus, Alternaria and Drechslera) were positive in all patients; two (Penicillium and Curvularia) were positive in thirty-five patients; two (Cladosporium and Mycelia sterilia) were positive in thirty patients; and three (Rhizopus, Absidia and Fusarium) were positive in nine patients. All the control tests were negative. All the ten most predominant anemophilous fungi isolated in the air could provoke skin test reactivity in individuals with respiratory allergy in Fortaleza.

Os fungos anemófilos estão dispersos no ar atmosférico. O conhecimento dos fungos anemófilos em uma cidade é importante para o diagnóstico ecológico e o tratamento específico de manifestações alérgicas induzidas pela inalação de alérgenos. Os fungos alergênicos são usados para o diagnóstico e o tratamento da alergia em todo o mundo, o que provavelmente persistirá por muitos anos ainda. O objetivo deste trabalho foi fazer uma relação entre os fungos anemófilos e a alergia respiratória (asma e rinite) de pacientes da cidade de Fortaleza, Ceará. Primeiro foi feita uma pesquisa dos fungos alergênicos dispersos no ar atmosférico da cidade de Fortaleza. Os extratos fúngicos alergênicos foram feitos a partir dos dez bolores mais predominantes do ar de Fortaleza, usando bicarbonato de sódio. Foram feitos testes da puntura em cinqüenta pacientes com alergia respiratória (asma e rinite) e dez pessoas saudáveis (sem alergia respiratória). O teste positivo foi feito com histamina e o teste negativo com uma preparação de bicarbonato de sódio. Os fungos predominantes no ar da cidade de Fortaleza foram: Aspergillus, Penicillium, Curvularia, Cladosporium, Mycelia sterilia, Fusarium, Rhizopus, Drechslera, Absidia e Alternaria. Como demonstrado pelo teste da puntura: três extratos fúngicos (Aspergillus, Alternaria e Drechslera) foram positivos em todos os pacientes; dois (Penicillium e Curvularia) foram positivos em trinta e cinco pacientes; dois (Cladosporium e Mycelia sterilia) foram positivos em trinta pacientes; e três (Rhizopus, Absidia e Fusarium) foram positivos em nove pacientes. Todos os testes controles foram negativos. Todos os dez fungos anemófilos mais predominantes isolados no ar podem provocar reações nos testes cutâneos em indivíduos com alergia respiratória na cidade de Fortaleza.

\footnotetext{
1. Professor-doutor do Departamento de Análises Clínicas e Toxicológicas da Universidade Federal do Ceará.

2. Farmacêutico.

3. Médico alergologista e pneumologista; diretor do Centro de Pneumologia do Ceará.

4. Professor especialista da Universidade Estadual do Ceará.

5. Professor-doutor da Faculdade de Medicina da Universidade de São Paulo.

Financiamento: Fundação Cearense de Apoio ao Desenvolvimento Científico e Tecnológico (Funcap).
} 


\section{Introduction}

Fungi are eukaryotic, filamentous, and mostly sporebearing organisms, which exist as saprophytes or as parasites of animals and plants. The development of allergies to fungi follows the same biological phenomena as allergies to other environmental allergens. Fungal spores are ubiquitous and the number of fungal species present in the environment is estimated to be at least one million. Some genera of airborne fungal spores such as Alternaria, Aspergillus and Cladosporium are found throughout the world. The airborne spores of these fungi are generally considered to be important causes of both allergic rhinitis and allergic asthma ${ }^{(12)}$.

Research on airborne fungi has been performed worldwide over the last decades. Storm Van Leeuwen ${ }^{(26)}$ was the first to suspect that airborne fungi played a role in patients' allergy attacks. He found fungi in the home and in the mattresses of a patient in Holland who suffered from asthma, and he suspected the fungi could be the causative agents. Others in Germany and the United States studied airborne fungi as the causative agents of asthma and hay fever in many patients( ${ }^{(6)}$. Towey et al. have reported an asthma incident in a patient who was exposed to fungal spores from the bark of maple logs, and Cobe has described a similar case in which a greenhouse worker suffered an asthma attack after inhaling spores from Cladosporium grown on a tomato plant ${ }^{(1)}$.

Fungi are associated with a number of allergic diseases in humans. The prevalence of respiratory allergy to fungi is estimated at $20 \%$ to $30 \%$ among atopic individuals and up to $6 \%$ in the general population. The major allergic manifestations induced by fungi are asthma, rhinitis, allergic bronchopulmonary mycoses, and hypersensitivity pneumonitis. These diseases can result from exposure to spores, vegetative cells, or metabolites of the fungi(22).

Diagnosis of allergic disease is mainly based on clinical symptoms of the patients, skin test, detection of allergenspecific serum lgE antibodies, and in some cases provocative inhalation challenge test. The effective in vivo and in vitro diagnosis of fungal allergies is based on the availability of well-characterized allergen preparations ${ }^{(12)}$.

The allergenicity of an extract can be evaluated by skin testing allergic patients. Two types of skin reactions can be observed in allergic patients. Type I (immediate) reactivity consists of a wheal and flare within five to 20 minutes of antigen challenge. Type II reaction (Arthus reaction) is an induration usually developed within four to eight hours after skin testing ${ }^{(4)}$.

The prick test is a variation of the puncture test. A drop of antigen is applied to the test site. The point of a needle is passed obliquely through the drop of the antigen into the epidermis. The skin is gently lifted by the needle as it is withdrawn. Care is taken not to cause bleeding. The technique is simple and requires minimal technical skill. The reactions are generally smaller than for the scratch tests and the results are read in a similar manner and time ${ }^{(1)}$.

Several fungi found in dust and air carry out the medical pathology, like allergic components. Thus several origins of asthma and rhinitis depend on the mycota of the air ${ }^{(4)}$. Large numbers of airborne spores are usually present in outdoor air, depending on environmental factors such as water, nutrients, temperature and wind. Most fungi commonly considered allergenic have a seasonal spore-releasing pattern ${ }^{(8)}$.

The purpose of this research was to establish a relationship between the anemophilous fungi isolated in the air and patients with respiratory allergy, and show the fungal extracts that could provoke skin test reactivity in individuals with respiratory allergy (asthma and rhinitis) in the city of Fortaleza.

\section{Material and method}

\section{Isolation of airborne fungi}

The airborne fungi dispersed in the atmospherical air in Fortaleza was isolated in ten locations every week during a year; spores were collected using Petri dishes containing a medium of Sabouraud's dextrose agar. With the exception of rainy days, they were exposed to the air for 15 minutes, at 1.5 meters above the ground. A total of 360 Petri dishes were exposed.

The city of Fortaleza is located on the east coast of the state of Ceará, Brazil, at latitude $3^{\circ} 43^{\prime} 2^{\prime \prime}$ south and longitude $38^{\circ} 32^{\prime} 35^{\prime \prime}$ west. Climate is tropical wet, with an average annual temperature between $26^{\circ} \mathrm{C}$ and $28^{\circ} \mathrm{C}$. Typically there are two seasons: rainy and dry. The rainy season extends from February to July, with slightly lower temperatures ${ }^{(10)}$.

After seven days at environment temperature colonies were isolated in the same medium to observe formation of macrocolonies. Micromorphology was observed after slide culture, following technique described by Riddel(21), and the fungal strains were identified using the classifications of Barnett and Hunter ${ }^{(3)}$, Kreger-van Rij ${ }^{(11)}$ and MacGinnis et al.(15). Wirtz staining was used for the identification of asci. Biochemical tests, such as urease enzyme research and saccharose fermentation, were also used for the identification of different genera. Non-sporulating fungi were transferred to agar potatoes medium and kept at room temperature under white light, for between seven and ten days, to sporulate ${ }^{(13)}$. 


\section{Study patients}

Fifty patients with allergic respiratory disease (asthma and rhinitis) who earlier showed varying degrees of positive skin test reactivity to various allergens, ranging in age from ten to 65 years, entered the study. All patients lived in Fortaleza and in the locations where the collections of the airborne fungi were accomplished. The research was made in Centro de Pneumologia do Ceará, in Fortaleza. Ten non-allergic volunteers (students of medicine and pharmacy of the Federal University of Ceará) who acted as the control group were studied after their informed written consent was obtained.

\section{Preparation of the fungi extracts}

Fungal extracts were made of the ten predominant airborne mould collected from the air of Fortaleza: Aspergillus, Penicillium, Curvularia, Cladosporium, Mycelia sterilia, Fusarium, Rhizopus, Drechslera, Absidia and Alternaria.

The fungi extracts were made using sodium bicarbonate ${ }^{(16)}$. The ten airborne fungi were grown at $25^{\circ} \mathrm{C}$ for 28 days and the fungi extracts were made using $10 \%$ sodium bicarbonate preparation. The sterilization of the extracts was made with $0.02 \mathrm{~mm}$ millipore membrane and the sterilization test of the extracts was made with $\mathrm{BHI}$ and Sabouraud's dextrose broth ${ }^{(17)}$.

\section{Skin test}

The prick tests were made in fifty patients with allergic respiratory disease (asthma and rhinitis), and in ten nonallergic volunteers (students of medicine and pharmacy) who acted as the negative control group, after their informed written consent was obtained ${ }^{(9)}$. The tests were made in the Centro de Pneumologia do Ceará in Fortaleza. The extracts used in the tests were made of the ten airborne mould most predominant in the city ${ }^{(19)}$. The positive test was made with histamine and the negative test with sodium bicarbonate preparation; the readings were taken according to Shivpuri's ${ }^{(24)}$ criteria.

\section{Results}

The 360 Petri dishes exposed yielded 1.521 colonies of 24 genera. Non-sporulating strains were grouped in Mycelia sterilia. Table 1 shows the absolute frequency of fungi of the ten collection sites in the city of Fortaleza. The genera of the ten airborne fungi with higher absolute frequency were: Aspergillus (44.7\%), Penicillium (13.3\%), Curvularia (9.8\%), Cladosporium (6.8\%), Mycelia sterilia (6\%), Fusarium (3.5\%), Rhizopus (3.1\%), Drechslera (2.6\%), Alternaria (2.4\%) and Absidia (2.2\%). In this work it was verified that the Aspergillus is the most predominant genera, with nearly half of the airborne fungi of Fortaleza (44.7\%). Other relevant data is that the collection site Aldeota was the place where most airborne fungi were isolated (314 colonies), it is the location of the Centro de Pneumologia do Ceara and where the majority of the patients live.

Table 2 and the Figure show the number of positive prick tests of the patients with allergic respiratory diseases at Centro de Pneumologia do Ceará. The extracts used were of the ten most predominant airborne fungi in Fortaleza. Of the fifty patients evaluated, all had positive response to Aspergillus, Alternaria and Drechslera extracts as determined by prick test. Seventy per cent of the patients evaluated had positive response to Penicillium and Curvularia extracts, $60 \%$ of the patients had positive response to Cladosporium and Mycelia sterilia extracts and $18 \%$ had positive response to Rhizopus, Absidia and Fusarium extracts. None of the control patients (non-allergic volunteers, $n=10$ ) had positive responses to prick tests.

\section{Discussion}

Fungi disseminate their spores in the environment through the atmospheric air, water, insects, man, and animals. Airborne fungi are those which are spread by the atmospheric air. Qualitative knowledge of these fungi in a given region is of great importance and concern because they can cause several respiratory diseases in man such as asthma and rhinitis when inhaled ${ }^{(18)}$. In the present study, a relationship between isolated airborne fungi and respiratory allergy patients from Fortaleza was demonstrated.

Among the airborne fungi that spread air spores and are important aeroallergens of the world are Aspergillus, Cladosporium, Alternaria, Penicillium, Drechslera ${ }^{(1)}$. These data are similar to those found in our work. The predominant airborne fungi in the air of Fortaleza were: Aspergillus, Penicillium, Curvularia, Cladosporium, Mycelia sterilia, Fusarium, Rhizopus, Drechslera, Absidia and Alternaria (Table 1).

One of the most thorough studies of airborne fungi performed in Brazil was made by Gambale et al.(7) in 1983. They studied the state of São Paulo. They classified several fungi: Cladosporium, Drechslera, Fusarium, Alternaria, Penicillium, Aspergillus, hyphal fragments, smuts, phycomycetes, ascomycetes, basidiomycetes, imperfect fungi and many others.

A similar study by Mezzari et al.(18) revealed a prevalence of airborne fungi in the city of Porto Alegre; the most predominant fungi found in the air of the city were: Caldosporium, Aspergillus, Penicillium, Curvularia, Alternaria, Fusarium and others. We obtained similar results in our work; the most frequently found genera in Fortaleza were the same identified in Porto Alegre (Table 1). 
Table 1

\section{Absolute frequency of the airborne fungi genera isolated in the city of Fortaleza in the ten} collection sites within it

\begin{tabular}{|c|c|c|c|c|c|c|c|c|c|c|c|c|}
\hline & $\mathrm{CE}$ & $\mathrm{AL}$ & $\mathrm{BF}$ & $A B$ & RT & $\mathrm{CF}$ & $\mathrm{BC}$ & MO & $\mathrm{PA}$ & $P P$ & $\begin{array}{l}\mathrm{N}^{0} \text { of } \\
\text { colonies }\end{array}$ & $\%$ \\
\hline Aspergillus & 44 & 152 & 37 & 54 & 43 & 52 & 100 & 35 & 48 & 117 & 682 & 44.7 \\
\hline Penicillium & 13 & 52 & 22 & 18 & 15 & 15 & 27 & 12 & 18 & 12 & 204 & 13.3 \\
\hline Curvularia & 8 & 58 & 6 & 7 & 18 & 13 & 14 & 8 & 11 & 6 & 149 & 9.8 \\
\hline Cladosporium & 9 & 17 & 1 & 1 & 11 & 15 & 15 & 5 & 9 & 21 & 104 & 6.8 \\
\hline Mycelia sterilia & 4 & 2 & 15 & 22 & 8 & 9 & 7 & 9 & 8 & 8 & 92 & 6 \\
\hline Fusarium & 5 & 4 & 1 & 3 & 2 & 7 & - & 5 & 14 & 13 & 54 & 3.5 \\
\hline Rhizopus & 4 & 3 & 8 & 12 & 3 & 5 & 3 & 6 & 2 & 2 & 48 & 3.1 \\
\hline Drechslera & 3 & 8 & 3 & - & 5 & 3 & 2 & 3 & 3 & 7 & 37 & 2.6 \\
\hline Absidia & 4 & 3 & - & 5 & 3 & 5 & - & 1 & 15 & - & 33 & 2.2 \\
\hline Alternaria & - & 8 & 6 & 2 & 5 & 7 & 3 & - & 1 & 1 & 36 & 2.4 \\
\hline Neurospora & 2 & - & - & 2 & 2 & 6 & 2 & 2 & 5 & - & 21 & 1.4 \\
\hline Rhodotorula & - & 1 & 2 & 5 & 3 & - & 1 & 2 & - & - & 14 & 0.9 \\
\hline Aureobasidium & - & 1 & 2 & 2 & - & - & 2 & - & - & - & 7 & 0.5 \\
\hline Cunninghamela & - & - & - & - & 1 & - & - & 4 & 1 & - & 6 & 0.4 \\
\hline Mucor & - & - & - & - & 1 & - & - & 2 & 1 & - & 6 & 0.4 \\
\hline Epicoccum & - & - & - & 1 & 2 & - & - & 2 & 1 & - & 6 & 0.4 \\
\hline Syncephalastrum & 2 & 2 & - & - & - & - & - & 1 & 1 & - & 6 & 0.4 \\
\hline Paecilomyces & - & - & - & - & 1 & - & - & - & 3 & - & 4 & 0.3 \\
\hline Acremonium & - & - & - & - & - & 3 & - & - & - & - & 3 & 0.2 \\
\hline Nigrospora & - & - & - & - & 1 & - & - & 1 & - & - & 2 & 0.15 \\
\hline Verticilium & - & 1 & - & - & - & - & - & - & 1 & - & 2 & 0.15 \\
\hline Geotrichium & 1 & - & 1 & - & - & - & - & - & - & - & 2 & 0.15 \\
\hline Trichoderma & - & - & - & - & - & - & - & 1 & - & 1 & 2 & 0.15 \\
\hline Phoma & - & - & - & - & - & - & - & 1 & - & - & 1 & 0.1 \\
\hline Total & 99 & 314 & 104 & 134 & 124 & 140 & 176 & 100 & 142 & 188 & 1.521 & 100 \\
\hline
\end{tabular}

CE: downtown; AL: Aldeota; BF: Bairro de Fátima; AB: Antônio Bezerra; RT: Rodolfo Teófilo; CF: Cidade dos Funcionários, BC: Barra do Ceará, MO: Mondubim, PA: Parangaba, PP: Papicu.

\section{Prick tests in patients with allergic respiratory disease at Centro de Pneumologia do Ceará}

Table 2 and percentage of patients that presented positive responses

\begin{tabular}{lcc}
\hline Fungi extracts & $N^{0}$ of positive patients & $\%$ \\
Aspergillus & 50 & 100 \\
Alternaria & 50 & 100 \\
Drechslera & 50 & 100 \\
Penicillium & 35 & 70 \\
Curvularia & 35 & 70 \\
Cladosporium & 30 & 60 \\
Mycelia sterilia & 30 & 60 \\
Rhizopus & 9 & 18 \\
Absidia & 9 & 18 \\
Fusarium & 9 & 18 \\
\hline
\end{tabular}

Schoenlein-Crusius et al.(23) in a similar study found that the airborne fungi of Cubatão, a city in the state of São Paulo, where air pollution is caused by fertilizer industries, steel works, cement factories and chemical products industries, among others, were composed of 19 common, ten rare and two constant fungal species. Among the obtained fungi, at least 12 genera were reported as opportunistic fungi, 26 have been mentioned related to plant diseases and eight have been associated to respiratory allergy. In our work we found several fungi associated to allergic respiratory diseases.

Fungal spores are specially important in the tropics, in which climatic conditions are very favorable to the growth of fungi and may result in a high concentration of spores in the 


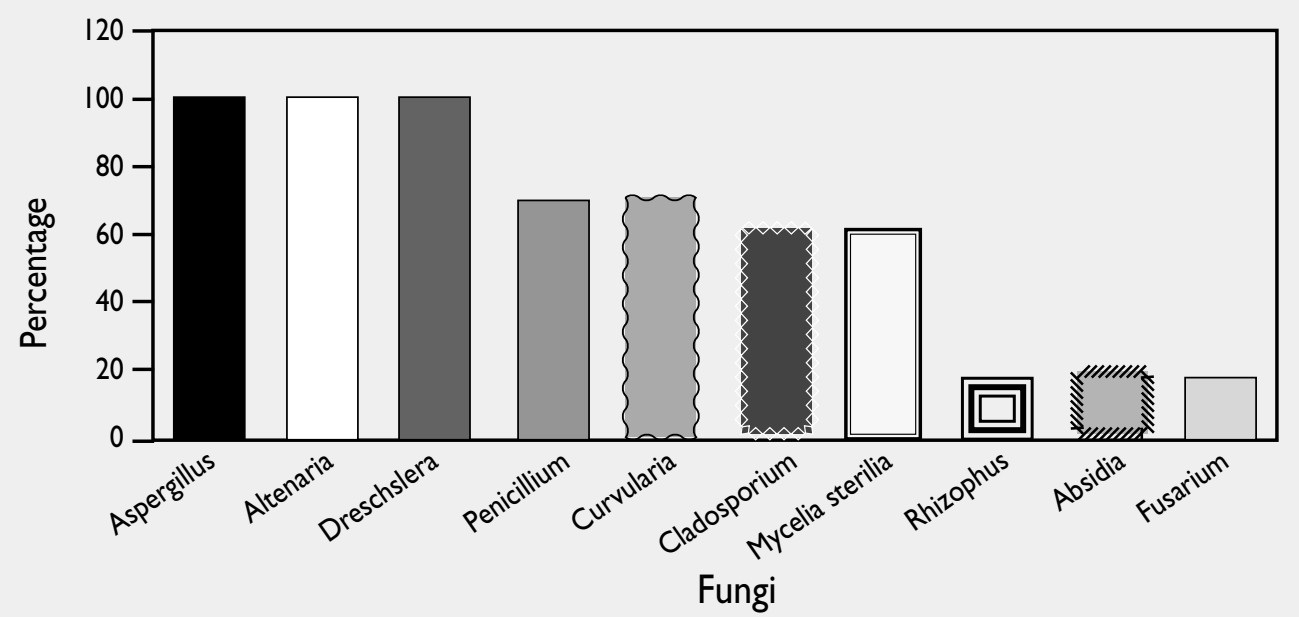

Figure - Prick tests in patients with allergic respiratory disease at Centro de Pneumologia do Ceará and percentage of patients that presented positive responses

air, which in turn causes an increased incidence of allergic diseases ${ }^{(1)}$. In several countries Penicillium and Aspergillus had the higher concentration of spores (1), as in our study. Rhizopus, Mucor and Absidia are more common in higher places, such as São Paulo and Quito(1); Fortaleza is ground level and had a lower concentration of these spores in the air.

"The skin test is a deliberate and controlled exposure to a suspected allergen conducted mainly to confirm clinical atopic sensitivity. It involves an interaction between the allergen and lgE fixed to mast cells in the skin with liberation of chemical mediators, resulting in local erythema and wheal formation"(2). "A basic premise of skin testing is that reaginic antibody will fix to the skin mast cell in a manner similar to that occurring in the various target organs. Widespread use of the skin test as a diagnostic aid began in the early part of this century"(14). "It was hoped that skin testing would separate the atopic population sensitive to an allergen from the non-allergic group. Skin testing was quickly adopted and has become the primary method for detecting etiologically important factors in atopic disease" ${ }^{\prime \prime(1)}$.

"The prick test is preferred by many because it is more specific, sensitive and reproducible. There is a better separation of clinically sensitive patients from normal controls and irritant reactions are also less common. The advantages include the ability to do multiple tests easily and in a very cost-efficient manner. The major disadvantage of the test is the lack of adequate control of the length and depth of the abrasion"(1); another important disadvantage is the cross reactivity among the airborne fungi.

In our study we made prick test and the results showed the skin tests of the patients with allergic respiratory disease in Centro de Pneumologia do Ceará, in Fortaleza (Table 2 and Figure). The extracts used were obtained from the most predominant airborne fungi in Fortaleza. Of the fifty patients evaluated, all had positive response to Aspergillus, Alternaria and Drechslera extracts as determined by prick test; $70 \%$ of the patients evaluated had positive response to Penicillium and Curvularia extracts; $60 \%$ of the patients had positive response to Cladosporium and Mycelia sterilia extracts and $18 \%$ had positive response to Rhizopus, Absidia and Fusarium extracts. None of the control patients (non-allergic volunteers, $n=10$ ) had positive responses to prick tests. The importance of this study was that all ten fungi extracts tested were positive.

Pepys and Davies ${ }^{(20)}$ have considered all positive prick reactions to be significant; they compared all prick tests to a histamine control and the negative control, the sodium bicarbonate. In this study the importance of the relation between positive and negative control was also considered.

In the immediate hypersensitivity response, several host factors appear important for sensitization, such as genetic disposition, allergen exposure, entry route of allergens, local microcirculation, and homeostatic factors. A set of genetically determined dispositions may be decisive. To make the genetic disposition manifest, however, sufficient exposure to agents with appropriate antigenic potential is essential(5). Grenn et al. ${ }^{(8)}$ studied allergens from a range of fungal spores before and after germination; they showed that allergens dispersed by airborne fungal spores play an important but poorly understood role in the underlying cause and exacerbation of asthma and rhinitis.

Aspergillus, Cladosporium, Alternaria and Penicillium are the most abundant fungi found in all world environments and are a major source of inhalant fungal allergens. They have been reported as the predominant organisms in warm, humid and dry climates ${ }^{(12)}$. These airborne fungi are common in the air of Fortaleza.

Biologic standardization is a mean for defining the potency of allergen extracts by skin prick testing in 
groups of patients with relevant sensitivity to the allergens in question ${ }^{(25)}$. Insufficient concentration of allergens, therefore, in addition to the possible absence of some allergens in fungi extracts, may explain the false negative skin prick tests observed in this study. This may explain the apparent lack of efficacy of immunotherapy with conventional fungal extracts. The importance of this research is to know the several fungi able to cause asthma and rhinitis in the population of Fortaleza; these fungi are in the atmosphere as contaminants of the air.

\section{Conclusions}

- Predominant fungi in the air of Fortaleza were: Aspergillus, Penicillium, Curvularia, Cladosporium, Mycelia sterilia, Fusarium, Rhizopus, Drechslera, Absidia and Alternaria;
- all fifty patients with allergic respiratory disease evaluated had positive response to Aspergillus, Alternaria and Drechslera extracts as determined by prick test;

- thirty-five patients with allergic respiratory disease evaluated had positive response to Penicillium and Curvularia extracts as determined by prick test;

- thirty patients had positive response to Cladosporium and Mycelia sterilia extracts;

- nine patients had positive response to Rhizopus, Absidia and Fusarium extracts as determined by prick tests;

- all the ten most predominant anemophilous fungi isolated in the air could provoke skin test reactivity in individuals with respiratory allergy in the city of Fortaleza.

\section{References}

I. AL-DOORY, Y.; DOMSON, J. F. Mould allergy. Philadelphia: Ed. Lea et Febigher, 1984.

2. BAPNA, A.; MATHUR, U. S. The relationship of allergic bronchial asthma, cutaneous sensitivity and serum IgE. Lung India, v. 8, p. 76-8, 1990.

3. BARNETT, H. L.; HUNTER, B. B. Illustrated genera of imperfect fungi. $3^{\text {rd }}$ ed. Minneapolis: Burgess Publishing, 1972.

4. BLUMENTHAL, M. N.; ROSENBERG, A. Fungal allergy. In: LOCKEY, R. F.; BUKANTZ, S. C. (Ed.). Allergens and allergen immunotherapy. New York: Marcel Dekker Inc., |999. p. 39-51.

5. CROCE, J. et al. Provocation of asthma by non-sporulating molds. In: KOBAYASHI, S.; BELLANTI, J.A. (Ed.). Advances in asthmologia. Amsterdam: Excerta Medica, 1990. p. $40 \mathrm{I}-4$.

6. FISH, J. E. Bronchial challenge testing. In: MIDDLENTON JR E. et al. (Ed.). Allergy: principles and practice. $3^{\text {rd }}$ ed. St. Louis: CV Mosby Company, 1988. p. I I22-38.

7. GAMBALE,W.; PURCHIO, A.; PAULA, C. R. Influência de fatores abióticos na dispersão aérea de fungos na cidade de São Paulo, Brasil. Rev Microbiol, v. I4, p. 204-| 4, 1983.

8. GREEN, B.J:; MITAKAKIS,T.Z:; TOYER, E. R.Allergen detection from I I fungal species before and after germination. I Allergy Clin Immunol, v. I I I, n. 2, p. 285-9, 2003.

9. GRONRMYER,W. Execução e avaliação do teste por puntura (prick test). In: Manual alergológico. Divisão de Alergia Merck, 1990.

10. KRAMER, C. L.; PADY, S. M.; WILEY, B. J. Kansas Aeromycology XIV Diurnal Studies. Trans Kans Acad Sci, v. 67, p. 442, 1984.

I I. KREGER-VAN RIJ, N. J.W. The yeast: a taxonomy study. $3^{\text {rd }}$ ed. Amsterdam: Elsevier Science Publishers BV, 1984.

12. KURUP, V. P; SHEN, H. D.; BANERJEE, B. Respiratory fungal allergy. Microbes and infection, v. 9, n. 2, p. II0I-10, 2000.

13. LACAZ, C. S. et al. Tratado de Micologia Médica. $9^{a}$ ed. São Paulo: Editora Sarvier, 2002.

I4. MALLING, H. J. Diagnosis and immunotherapy of mold allergy. IV. Relation between asthma symptoms, spore counts and diagnostic tests. Allergy, v. 4I, p. 342-50, 1986.

I5. McGINNIS, M. R.; D'AMATO, R. F.; LAND, G. A. Pictorial handbook of medically important fungi and aerobic actinomyces. Ed. Praeger Special Studies, 1980.
16. MENEZES, E. A. et al. Characterization of allergenic fractions from Drechslera monoceras.J Invest Allergol Clin Immunol, v. 8 , n. 4, p. 2। 4-8, 1998.

17. MENEZES, E. A. Biochemical antigenic and allergenic characterization of crude extracts of Drechslera (Helminthosporium) monoceras. Mycopathologia, v. I31, p. 75-8I, 1995.

18. MEZZARI, A. et al. Airborne fungi in the city of Porto Alegre, Rio Grande do Sul, Brazil. Ver Inst Med Trop S. Paulo, v. 44, n. 5, p. 269-72, 2002.

19. MOHOVIC, J.; GAMBALE, W.; CROCE, J. Cutaneous positivity in patients with respiratory allergens to 42 allergenic extracts of airborne fungi isolated in São Paulo, Brazil. Allergol Immunopathol, v. 16, p. 397-402, 1988.

20. PEPYS, J.; DAVIS, R. J. Allergy in asthma. T.J.H. CLARK and GODFREY (Ed.). Philadelphia:W.B. Saunders, 1977.

21. RIDDEL, R. W. Permanent stained mycological preparations obtained by slide culture. Mycologia, v. 42, p. 265, 1950.

22. SARMA, P. U. et al. Immunology and allergy clinics of North America. In: KURUP, V. P.; APTER, A. J. (Eds.). Philadelphia: WB Saunders, p. 525-47, 1998

23. SCHOENLEIN-CRUSIUS, I. H. et al. Airborne fungi in the region of Cubatão, São Paulo State, Brazil. Brazilian Journal of Microbiology, v. 32, p. 6I-5, 200 I.

24. SHIVPURI, D. N. Comparative evaluation of sensitivity of common methods of diagnostic antigen tests in patients of respiratory allergy. Ind J Chest Dis, v. 4, p. 102, 1962.

25. SPEELBURG, B.; EGIDIUS, A. H.; PANIOS, M. D. Late asthmatic responses after exercise challenge are reproducible.J Allergy Clin Immunol, v. 87, p. II28-37, 1991.

26. STORM Van LEEUWEN, W. Weitere untersuchunger uber asthma und Klima Klin. Wochenschr, v. 4, p. 1294; 1925.

\begin{tabular}{l|l} 
& Mailing address \\
\hline & Everardo Albuquerque Menezes \\
R. Henriqueta Caleno 1.000/701 - Dionísio Torres \\
CEP 60135-420 - Fortaleza-CE - Brasil \\
e-mail: menezes@ufc.br \\
Tel.: (85) 288-8266 \\
Fax: (85) 288-8292
\end{tabular}

